\title{
The Availability of Antidementia Drugs in Europe
}

\author{
a report by \\ Jean Georges \\ Executive Director, Alzheimer Europe
}

DOI:10.17925/ENR.2007.00.01.40

\section{Existing Treatments for Alzheimer's Disease in Europe}

No drug treatments can cure Alzheimer's disease or the other common forms of dementia. However, drug treatments have been developed that can temporarily slow the progression of symptoms in some people with Alzheimer's disease. Donepezil, rivastigmine and galantamine all work in a similar way and are known as acetylcholinesterase inhibitors (Achls). Memantine ${ }^{1}$ works in a different way from the other three. ${ }^{2}$

\section{Acetylcholinesterase Inhibitors}

Research has shown that the amount of a chemical called acetylcholine diminishes in the brains of people with Alzheimer's disease. Acetylcholine is one of the many chemicals that nerve cells use to communicate and is a neurotransmitter that plays a critical role in memory and learning processes.

Donepezil, rivastigmine and galantamine have a common mode of action - all three drugs prevent an enzyme known as acetylcholinesterase from breaking down acetylcholine in the brain. However, rivastigmine inhibits both acteylcholinesterase and butyrylcholinesterase, the two enzymes that break down acetylcholine in the brain. Galantamine also appears to act on the nicotinic neuronal receptors in the brain, making them release more acetylcholine. Increased concentrations of acetylcholine lead to improved communication between the nerve cells involved in memory and learning, which may in turn temporarily improve or stabilise some of the key symptoms of Alzheimer's disease.

It is possible that one of these drugs might suit a particular individual better than another. A specialist may be able to advise whether there is any advantage associated with a particular drug.

At present, Achls are used only in people with mild to moderate Alzheimer's disease. They are not effective for everyone and may only temporarily improve memory or delay memory loss. Research is being

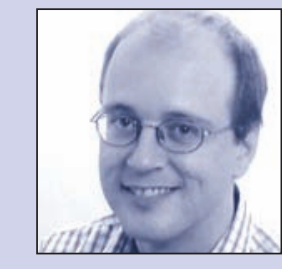

Jean Georges is the Executive Director of Alzheimer Europe and has been Project Manager of the various European projects run by the organisation. In 2000, he was elected to the Board of the European Federation of Neurological Associations and was its Secretary General from 2002 to 2004. In 2006, he was elected as Vice-President of the European Patients' Forum and represents the organisation in the working group on the effectiveness of the Pharmaceutical Forum set up by the European Commission. In 2003, he was appointed to the advisory panel of the British Medical Journal and to the European Medicines Agency (EMEA) working group with patient organisations, and in 2004 to the European Federation of Neurological Societies task force for the revision of its dementia guidelines. In 2005, he was appointed by the Council of Ministers and the European Parliament as one of two patient representatives to the EMEA management board.

E: jean.georges@alzheimer-europe.org undertaken to find out whether any of these drugs may be effective in the later stages of Alzheimer's disease. ${ }^{3}$

In February 2006, following a positive opinion from the Committee for Medicinal Products for Human Use (CHMP) of the European Medicines Agency (EMEA), the European Commission granted rivastigmine EU Marketing Authorisation for the symptomatic treatment of mild to moderately severe dementia associated with idiopathic Parkinson's disease (PDD).

\section{Memantine}

The action of memantine is different from that of the Achls. Memantine blocks another neurotransmitter in the brain known as glutamate. Glutamate is released in excessive amounts when brain cells are damaged by Alzheimer's disease, causing the brain cells to be damaged further. Memantine is thought to protect brain cells by blocking this release of excess glutamate.

Memantine can temporarily slow down the progression of symptoms in people in the middle and later stages of the disease. This is the first time a drug has been available for this group of people. There is also a suggestion that memantine may slow down the disease process itself. ${ }^{4}$

At first, memantine was licensed for the treatment of moderately severe to severe Alzheimer's disease, but, following a positive opinion from the CHMP of the EMEA in October 2005, the European Commission granted memantine an extension of the indication to the treatment of patients with moderate to severe Alzheimer's disease.

\section{Inequalities in Access to Alzheimer Treatments in Europe}

In its Strategic Plan (2006-10), Alzheimer Europe has provided a clear mission statement for its work. Its core objective is defined as "changing perceptions, policy and practice in order to improve the access by people with dementia and their carers to treatment options and care services".

Access by European citizens to existing antidementia drugs is, of course, a key concern of Alzheimer associations throughout Europe. In 2005 and 2006, Alzheimer Europe co-ordinated a response of its national organisations to the appraisal document of the National Institute for Health and Clinical Excellence (NICE) in the UK on the treatments available for Alzheimer's disease. In its response, the organisations expressed their grave concern about the proposal to limit access of UK citizens to treatments that are available to people with Alzheimer's disease in other European countries.

As a follow-up to this response and as part of its European Commission-financed project, the European Collaboration on Dementia (EuroCoDe), Alzheimer Europe carried out an extensive 
Table 1: Authorisation and Reimbursement of Alzheimer Drugs in Europe

\begin{tabular}{|c|c|c|c|c|c|c|c|c|}
\hline \multirow[t]{2}{*}{ Country } & \multicolumn{2}{|c|}{ Donepezil } & \multicolumn{2}{|c|}{ Rivastigmine } & \multicolumn{2}{|c|}{ Galantamine } & \multicolumn{2}{|c|}{ Memantine } \\
\hline & A & $R$ & A & $R$ & A & $\mathrm{R}$ & A & $R$ \\
\hline Austria & Yes & Yes & Yes & Yes & Yes & Yes & Yes & Yes \\
\hline Belgium & Yes & Yes & Yes & Yes & Yes & Yes & Yes & Yes \\
\hline Bulgaria & Yes & No & Yes & No & Yes & No & No & No \\
\hline Cyprus & Yes & Yes & Yes & Yes & Yes & Yes & Yes & Yes \\
\hline Czech Republic & Yes & Yes & Yes & Yes & Yes & Yes & Yes & Yes \\
\hline Denmark & Yes & Yes & Yes & Yes & Yes & Yes & Yes & Yes \\
\hline Estonia & Yes & Yes & Yes & No & Yes & Yes & Yes & Yes \\
\hline Finland & Yes & Yes & Yes & Yes & Yes & Yes & Yes & Yes \\
\hline France & Yes & Yes & Yes & Yes & Yes & Yes & Yes & Yes \\
\hline Germany & Yes & Yes & Yes & Yes & Yes & Yes & Yes & Yes \\
\hline Greece & Yes & Yes & Yes & Yes & Yes & Yes & Yes & Yes \\
\hline Hungary & Yes & Yes & Yes & Yes & No & No & Yes & Yes \\
\hline Iceland & Yes & Yes & Yes & Yes & Yes & Yes & Yes & Yes \\
\hline Ireland & Yes & Yes & Yes & Yes & Yes & Yes & Yes & Yes \\
\hline Italy & Yes & Yes & Yes & Yes & Yes & Yes & Yes & No \\
\hline Latvia & Yes & No & Yes & No & Yes & No & Yes & No \\
\hline Lithuania & Yes & Yes & No & No & Yes & No & Yes & Yes \\
\hline Luxembourg & Yes & Yes & Yes & Yes & Yes & Yes & Yes & Yes \\
\hline Malta & Yes & No & Yes & No & Yes & No & Yes & No \\
\hline The Netherlands & No & No & Yes & Yes & Yes & Yes & Yes & Yes \\
\hline Norway & Yes & Yes & Yes & Yes & Yes & Yes & Yes & No \\
\hline Poland & Yes & Yes $^{5}$ & Yes & Yes & Yes & No & Yes & No \\
\hline Portugal & Yes & Yes & Yes & Yes & Yes & Yes & Yes & Yes \\
\hline Romania & Yes & Yes & Yes & Yes & No & No & Yes & Yes \\
\hline Slovak Republic & Yes & Yes & Yes & Yes & Yes & Yes & Yes & Yes \\
\hline Slovenia & Yes & Yes & Yes & Yes & Yes & Yes & Yes & Yes \\
\hline Spain & Yes & Yes & Yes & Yes & Yes & Yes & Yes & Yes \\
\hline Sweden & Yes & Yes & Yes & Yes & Yes & Yes & Yes & Yes \\
\hline Switzerland & Yes & Yes & Yes & Yes & Yes & Yes & Yes & Yes \\
\hline Turkey & Yes & Yes & Yes & Yes & Yes & Yes & Yes & Yes \\
\hline United Kingdom & Yes & Yes & Yes & Yes & Yes & Yes & Yes & $\mathrm{No}^{6}$ \\
\hline
\end{tabular}

$A=$ authorised; $R=$ part of the reimbursement system.

survey of its members to highlight any inequalities within the EU with regard to the access of people with Alzheimer's disease to existing treatments. In its survey, Alzheimer Europe concentrated on finding out which of the available treatments were reimbursed under national health systems in different European countries, but also aimed at quantifying the delays experienced by different countries in granting such reimbursement, as well as any other access restrictions imposed by national health systems for the reimbursement of these medicines.

The Reimbursement of Alzheimer Treatments in Europe

Reimbursement systems in Europe vary quite considerably, but each European country has a system in place that guarantees that essential medicines are made available to patients at an affordable price that is at least partly underwritten by the national health systems. Table 1 shows whether the four drugs available for the treatment of Alzheimer's disease have been authorised nd whether they are part of the reimbursement system of the respective countries. However, there is no indication as to the level of reimbursement provided or the access restrictions imposed by the reimbursement systems.

As can be seen from Table 1, with the exception of Bulgaria, Latvia and Malta, one or more Achls are reimbursed in all the European countries covered by the Alzheimer Europe survey, even if there may be slight variations as to which of the medicines are available and reimbursed.
Table 2: Prescription and Reimbursement Criteria for Treatments of Alzheimer's Disease in Europe

\begin{tabular}{|c|c|c|c|c|c|}
\hline Country & $\begin{array}{c}\text { Initial } \\
\text { Treatment } \\
\text { Decision }\end{array}$ & $\begin{array}{c}\text { Continuing } \\
\text { Treatment } \\
\text { Decision }\end{array}$ & $\begin{array}{c}\text { Special } \\
\text { Examinations } \\
\text { Required }\end{array}$ & $\begin{array}{c}\text { Upper } \\
\text { and Lower } \\
\text { MMSE } \\
\text { Scores } \\
\text { (Achl) }{ }^{9}\end{array}$ & $\begin{array}{c}\text { Upper } \\
\text { and Lower } \\
\text { MMSE } \\
\text { Scores } \\
\text { (Memantine) }^{10}\end{array}$ \\
\hline Austria & $\begin{array}{l}\text { Specialist } \\
\text { doctors }\end{array}$ & $\begin{array}{c}\text { Specialist } \\
\text { doctors }\end{array}$ & MMSE & $26-10$ & $14-3$ \\
\hline Belgium & $\begin{array}{l}\text { Specialist } \\
\text { doctors }\end{array}$ & $\begin{array}{l}\text { Specialist } \\
\text { doctors }\end{array}$ & $\begin{array}{l}\text { Diagnostic } \\
\text { protocol }\end{array}$ & $>10$ & $15-0$ \\
\hline Bulgaria & & & o reimbursement & & \\
\hline Cyprus & & & No information & & \\
\hline $\begin{array}{l}\text { Czech } \\
\text { Republic }\end{array}$ & $\begin{array}{l}\text { Specialist } \\
\text { doctors }\end{array}$ & $\begin{array}{l}\text { Specialist } \\
\text { doctors }\end{array}$ & MMSE & $20-13$ & $16-6$ \\
\hline Denmark & $\begin{array}{c}\text { No } \\
\text { restrictions }{ }^{11}\end{array}$ & $\begin{array}{c}\text { No } \\
\text { restrictions }\end{array}$ & $\begin{array}{c}\text { Diagnostic } \\
\text { protocol }\end{array}$ & None & None \\
\hline Estonia & & & No information & & \\
\hline Finland & $\begin{array}{c}\text { No } \\
\text { restrictions }^{12}\end{array}$ & $\begin{array}{c}\text { No } \\
\text { restrictions }\end{array}$ & None & None & None \\
\hline France & $\begin{array}{l}\text { Specialist } \\
\text { doctors }\end{array}$ & $\begin{array}{c}\text { No } \\
\text { restrictions }\end{array}$ & None & $26-10$ & $15-0$ \\
\hline Germany & $\begin{array}{c}\text { No } \\
\text { restrictions }\end{array}$ & $\begin{array}{c}\text { No } \\
\text { restrictions }\end{array}$ & None & None & None \\
\hline Greece & $\begin{array}{l}\text { Specialist } \\
\text { doctors }\end{array}$ & $\begin{array}{c}\text { No } \\
\text { restrictions }\end{array}$ & None & None & None \\
\hline Hungary & $\begin{array}{l}\text { Specialist } \\
\text { doctors }\end{array}$ & $\begin{array}{l}\text { Specialist } \\
\text { doctors }\end{array}$ & $\begin{array}{c}\text { Diagnostic } \\
\text { protocol }\end{array}$ & $26-10$ & $18-0$ \\
\hline Iceland & $\begin{array}{c}\text { No } \\
\text { restrictions }{ }^{13}\end{array}$ & $\begin{array}{c}\text { No } \\
\text { restrictions }\end{array}$ & $\begin{array}{l}\text { Diagnostic } \\
\text { protocol }\end{array}$ & None & None \\
\hline Ireland & $\begin{array}{c}\text { No } \\
\text { restrictions }\end{array}$ & $\begin{array}{c}\text { No } \\
\text { restrictions }\end{array}$ & None & None & None \\
\hline Italy & $\begin{array}{c}\text { Alzheimer } \\
\text { evaluation } \\
\text { unit }\end{array}$ & $\begin{array}{c}\text { Alzheimer } \\
\text { evaluation } \\
\text { unit }\end{array}$ & $\begin{array}{c}\text { Diagnostic } \\
\text { protocol }\end{array}$ & $26-10$ & $n / a$ \\
\hline Latvia & & & No information & & \\
\hline Lithuania & & & MMSE & None & $20-0$ \\
\hline Luxembourg & $\begin{array}{c}\text { No } \\
\text { restrictions }\end{array}$ & $\begin{array}{c}\text { No } \\
\text { restrictions }\end{array}$ & $\begin{array}{c}\text { Diagnostic } \\
\text { protocol }\end{array}$ & $26-10$ & $15-0$ \\
\hline Malta & & & o reimbursement & & \\
\hline $\begin{array}{l}\text { The } \\
\text { Netherlands }\end{array}$ & $\begin{array}{c}\text { Specialist } \\
\text { doctors }\end{array}$ & $\begin{array}{l}\text { Specialist } \\
\text { doctors }\end{array}$ & $\begin{array}{c}\text { Diagnostic } \\
\text { protocol }\end{array}$ & $26-10$ & $14-3$ \\
\hline Norway & $\begin{array}{c}\text { No } \\
\text { restrictions }^{14}\end{array}$ & $\begin{array}{c}\text { No } \\
\text { restrictions }\end{array}$ & MMSE & $>12$ & $\mathrm{~N} / \mathrm{A}$ \\
\hline Poland & $\begin{array}{c}\text { No } \\
\text { restrictions }\end{array}$ & $\begin{array}{c}\text { No } \\
\text { restrictions }\end{array}$ & MMSE & $26-10$ & $\mathrm{~N} / \mathrm{A}$ \\
\hline Portugal & $\begin{array}{l}\text { Specialist } \\
\text { doctors }\end{array}$ & $\begin{array}{l}\text { Specialist } \\
\text { doctors }\end{array}$ & None & None & None \\
\hline Romania & $\begin{array}{l}\text { Specialist } \\
\text { doctors }\end{array}$ & $\begin{array}{l}\text { Specialist } \\
\text { doctors }\end{array}$ & $\begin{array}{l}\text { Diagnostic } \\
\text { protocol }\end{array}$ & $>12$ & $>12$ \\
\hline $\begin{array}{l}\text { Slovak } \\
\text { Republic }\end{array}$ & $\begin{array}{l}\text { Specialist } \\
\text { doctors }\end{array}$ & $\begin{array}{l}\text { Specialist } \\
\text { doctors }\end{array}$ & MMSE & $24-13$ & $24-13$ \\
\hline Slovenia & $\begin{array}{l}\text { Specialist } \\
\text { doctors }\end{array}$ & $\begin{array}{c}\text { No } \\
\text { restrictions }\end{array}$ & MMSE & $26-10^{15}$ & $26-10$ \\
\hline Spain & $\begin{array}{l}\text { Specialist } \\
\text { doctors }\end{array}$ & $\begin{array}{l}\text { Specialist } \\
\text { doctors }\end{array}$ & MMSE & None & None \\
\hline Sweden & $\begin{array}{c}\text { No } \\
\text { restrictions }\end{array}$ & $\begin{array}{c}\text { No } \\
\text { restrictions }\end{array}$ & None & None & None \\
\hline Switzerland & $\begin{array}{c}\text { No } \\
\text { restrictions }\end{array}$ & $\begin{array}{c}\text { No } \\
\text { restrictions }\end{array}$ & MMSE & $>10$ & $>3$ \\
\hline Turkey & $\begin{array}{l}\text { Specialist } \\
\text { doctors }\end{array}$ & $\begin{array}{c}\text { No } \\
\text { restrictions }\end{array}$ & None & None & None \\
\hline $\begin{array}{l}\text { United } \\
\text { Kingdom }\end{array}$ & $\begin{array}{l}\text { Specialist } \\
\text { doctors }\end{array}$ & $\begin{array}{c}\text { No } \\
\text { restrictions }{ }^{16}\end{array}$ & MMSE & $30-12$ & $\mathrm{~N} / \mathrm{A}$ \\
\hline
\end{tabular}


Table 3: Delays in Market Authorisation for Galantamine, Memantine and Rivastigamine

\begin{tabular}{|c|c|c|c|}
\hline & $\begin{array}{l}\text { Galantamine } \\
\text { Market Authorisation }\end{array}$ & $\begin{array}{l}\text { Memantine } \\
\text { Launch Dates }\end{array}$ & $\begin{array}{l}\text { Rivastigmine } \\
\text { Reimbursement } \\
\text { Dates }\end{array}$ \\
\hline First country & Sweden $(03 / 2000)$ & $\begin{array}{l}\text { Germany, Denmark, } \\
\text { Iceland (08/2002) }\end{array}$ & $\begin{array}{l}\text { Switzerland } \\
(03 / 1997)\end{array}$ \\
\hline Within six months & $\begin{array}{l}\text { Austria, Belgium, } \\
\text { Denmark, Finland, } \\
\text { Iceland, Ireland, } \\
\text { Norway, Switzerland, } \\
\text { United Kingdom }\end{array}$ & $\begin{array}{l}\text { Austria, Greece, } \\
\text { Ireland, The Netherlands, } \\
\text { Norway, Sweden, } \\
\text { United Kingdom }\end{array}$ & \\
\hline $\begin{array}{l}\text { Within six to } \\
12 \text { months }\end{array}$ & $\begin{array}{l}\text { France, Germany, } \\
\text { Greece, Italy, } \\
\text { Luxembourg, Poland, } \\
\text { Portugal, Spain }\end{array}$ & $\begin{array}{l}\text { Finland, France, } \\
\text { Hungary, Slovenia, } \\
\text { Spain }\end{array}$ & \\
\hline $\begin{array}{l}\text { Within one to } \\
\text { two years }\end{array}$ & $\begin{array}{l}\text { Czech Republic, } \\
\text { Lithuania, } \\
\text { Slovak Republic, } \\
\text { Slovenia }\end{array}$ & $\begin{array}{l}\text { Belgium, } \\
\text { Czech Republic, } \\
\text { Poland, Portugal, } \\
\text { Romania, } \\
\text { Slovak Republic, } \\
\text { Switzerland, Turkey }\end{array}$ & $\begin{array}{l}\text { France, Germany, } \\
\text { United Kingdom }\end{array}$ \\
\hline $\begin{array}{l}\text { Within two to } \\
\text { three years }\end{array}$ & & $\begin{array}{l}\text { Croatia, Italy, } \\
\text { Serbia-Montenegro }\end{array}$ & $\begin{array}{l}\text { Spain, The } \\
\text { Netherlands }\end{array}$ \\
\hline $\begin{array}{l}\text { Within three to } \\
\text { four years }\end{array}$ & $\begin{array}{l}\text { Latvia, Malta, } \\
\text { The Netherlands }\end{array}$ & Cyprus & Ireland \\
\hline Over four years & Cyprus & & $\begin{array}{l}\text { Austria, Belgium, } \\
\text { Hungary }\end{array}$ \\
\hline
\end{tabular}

Memantine, the most recent drug approved for the treatment of Alzheimer's disease, has not yet been made subject to a reimbursement decision in Bulgaria, Italy, Latvia, Malta, Norway or Poland. Similarly, most health trusts in the UK do not cover memantine under the National Health Service.

\section{Access and Reimbursement Restrictions}

The question of whether treatments for Alzheimer's disease are reimbursed under national health systems provides important information on the existing inequalities in access to treatment in Europe. Nevertheless, it does not provide a complete picture, since various conditions imposed by the health systems may impose further restrictions on the access of people with Alzheimer's disease to existing treatments.The changes proposed by NICE in the UK would, for example, limit the reimbursement of antidementia drugs to people in the moderate stages of the disease and exclude people with mild Alzheimer's disease.

Similarly, some countries have reserved reimbursement for treatment decisions made by specialist doctors or in specialist centres. Some have gone further by also requiring a continuing treatment decision to be made by a specialist doctor. Also, reimbursement may not be made available to people with Alzheimer's disease living alone or living in nursing homes. Other systems require specific examinations to be carried out prior to a reimbursement decision being made. Finally, there are quite considerable differences between European countries that have defined upper and lower Mini Mental State Examination (MMSE) score limits for the initiation and discontinuation of treatment. ${ }^{7}$ It is therefore not surprising that a recent article $^{8}$ warned about the "alarming arbitrariness" of these prescription and reimbursement criteria in Europe (see Table 2).

\section{Market Access Delays}

A final aspect that Alzheimer Europe covered in its survey on the availability of antidementia drugs concerned the dates of market authorisation, product launches and reimbursement decisions in the different countries. While differences in market authorisations already point to significant delays in some countries for the approval of new medicines, these delays are further exacerbated by the time it takes for pricing decisions to be made and for products to be launched, as well as for new treatments to be included in the reimbursement system.

Table 3 shows the delays experienced in some countries for market authorisation, launch or reimbursement decisions for three of the Alzheimer medicines.

Although it was impossible to find data for all the countries covered in our survey, the findings point to significant delays in some countries as to the access of people with Alzheimer's disease to treatment options available to patients in other countries. With the decision to centralise market authorisations for drugs for the treatment of neurodegenerative diseases - such as Alzheimer's disease - at the level of the EMEA, the delays between the Member States of the EU will disappear. Nevertheless, due to pricing discussions in some countries or internal company decisions, the launch dates of products will continue to vary and some people with Alzheimer's disease will have earlier access to new treatments than others.

Similarly, true access to antidementia drugs is obtained by patients only once these drugs are part of the reimbursement system, as otherwise treatment with these drugs may be limited only to those people who can afford to pay for them themselves. As can be seen from Table 3, although rivastigmine was authorised through the centralised procedure with European-wide marketing authorisation on 12 May 1998, there were significant differences as to the dates on which individual countries included this treatment in their reimbursement systems.

For Alzheimer Europe, these differences are unacceptable, and the organisation is campaigning for people with Alzheimer's disease throughout Europe to have equal access to a high standard of care services and treatment options.

\section{Treatment Rates}

The Alzheimer Europe survey shows important differences between European countries as to the numbers of people with Alzheimer's disease who have access to existing treatments. Other recent publications have similarly aimed at identifying differences in the numbers of people with Alzheimer's disease being treated.

A survey conducted by Pfizer among 200 carers from six different European countries (France, Germany, Italy, Poland, Spain and the UK) showed that a majority of physicians recommended treatment at the time of diagnosis. Nevertheless, there were marked differences between countries, with UK carers reporting that treatment was recommended at the time of diagnosis in only $51 \%$ of cases, whereas carers in Poland or Spain reported that this was the case in $86 \%$ of cases.

As to the treatment recommended, carers reported mainly prescription 


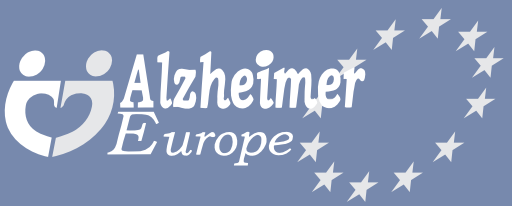

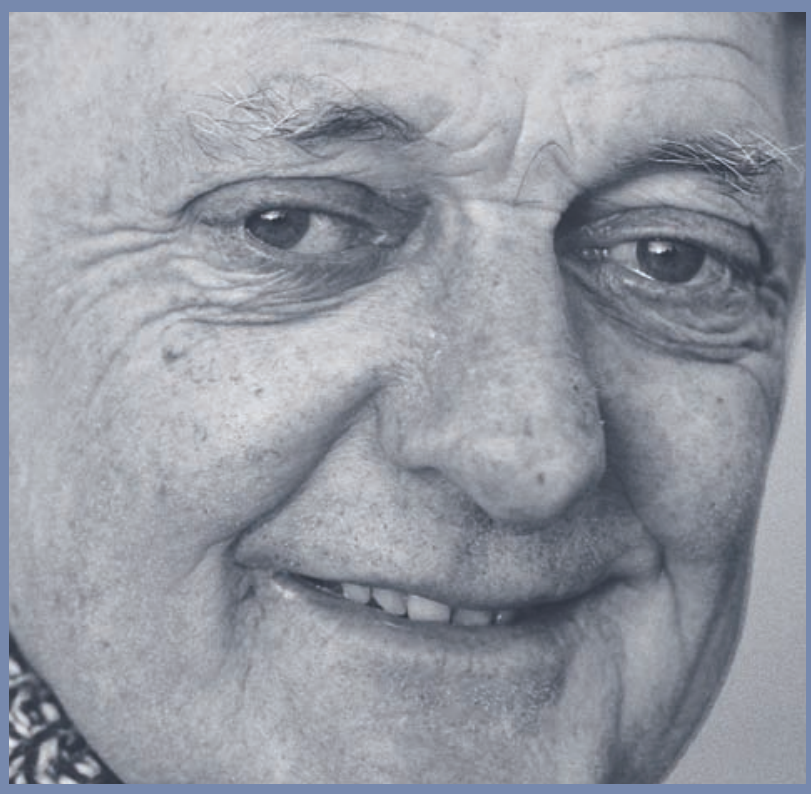

\section{Make Dementia a Public Health Priority by signing our declaration}

www.dementia-in-europe.eu

Alzheimer Europe has launched a new website dedicated to the public health impact of Alzheimer's disease and other forms of dementia in Europe. On this website, you will find the Paris Declaration on the political priorities of the European Alzheimer movement. This document was adopted unanimously at the Annual Meeting of Alzheimer Europe in Paris in June 2006 and is a veritable call for action on European policy makers to give dementia the public health priority it so justly deserves.

By collecting the greatest possible number of signatories, we want to show European and national policy makers the importance European citizens give to improving the situation of people with Alzheimer's disease and other forms of dementia. The full list of signatories will be submitted to the European Commissioner for Health at the end of 2007.

So please help us now to make dementia a public health priority by signing our declaration.

\section{SIGN OUR CAMPAIGN}

I hereby confirm that I support Alzheimer Europe's campaign and the policy priorities outlined in the Paris Declaration. I also authorise Alzheimer Europe to include my name on the list of individual supporters on the website and to submit my name along with other signatories to European and national policy makers whom Alzheimer Europe deems necessary to approach.

I am:

$\square$ a carer

$\square$ a care worker

$\square$ an Alzheimer association volunteer

$\square$ other supporter $\square$ a family member

$\square$ an Alzheimer association staff

$\square$ a policy maker a person with dementia

$\square$ a researcher

$\square$ a health care professional

First name:

Last name:

Email:

Town:

Country:

YOUR SIGNATURE: 
Table 4: Treatment Rates for Alzheimer's Disease in Europe

\begin{tabular}{|c|c|c|}
\hline Country & $\begin{array}{l}\text { Percentage of Carers Reporting } \\
\text { Treatment at Diagnosis }{ }^{19}\end{array}$ & $\begin{array}{c}\text { Percentage of } \\
\text { Patients Treated }{ }^{20}\end{array}$ \\
\hline Austria & & 32 \\
\hline Belgium & & 30 \\
\hline Bulgaria & & 6 \\
\hline Czech Republic & & 9 \\
\hline Denmark & & 28 \\
\hline France & 83 & 50 \\
\hline Germany & 78 & 26 \\
\hline Greece & & 97 \\
\hline Hungary & & 3 \\
\hline Ireland & & 46 \\
\hline Italy & 85 & 18 \\
\hline The Netherlands & & 8 \\
\hline Poland & 86 & 16 \\
\hline Portugal & & 33 \\
\hline Slovak Republic & & 10 \\
\hline Spain & 86 & 40 \\
\hline Sweden & & 47 \\
\hline Switzerland & & 28 \\
\hline United Kingdom & 51 & 18 \\
\hline
\end{tabular}

medicines (98\%) - either specific Alzheimer's treatments (86\%) or medication to treat mood and behaviour (61\%). Other therapies, such as counselling $(29 \%)$, day care (26\%), cognitive therapy $(21 \%)$ or support groups (15\%) were less often recommended by doctors. ${ }^{17}$

Similarly, a recent study by Waldemar et al. ${ }^{18}$ calculated the rates of people with Alzheimer's disease who receive treatment by combining the Alzheimer Europe prevalence rates with data obtained from international marketing services about the sales of donepezil, galantamine, rivastigmine and memantine (see Table 4).

\section{Conclusions}

The Alzheimer Europe survey and other studies in this field confirm that people with Alzheimer's disease do not have equal access to existing dementia treatments in Europe. Rather, access is subject to a great many restrictions and there are huge variations in access between European countries.

\section{Acknowledgements}

Alzheimer Europe gratefully acknowledges the input of the following individuals without whom it would have been impossible to collect this information:
ABELA Stephen, Malta Dementia Society, Malta

ALLARD Patrice, France Alzheimer, France

BARTSCH Roswitha, Alzheimer Angehörige Austria, Austria

BEDNARZ Bartosz, Novartis, USA

BASTIANI Pierluigi de, Italian Association for Alzheimer's Disease, Italy

BLOM Marco, Alzheimer Nederland, Netherlands

BYL Brigitte, Janssen-Cilag, Belgium

ESKILDSEN Thomas, Lundbeck, Denmark

GRANÖ Sirpa, Alzheimer-keskusliitto, Finland

GYLFADÓTTIR Gurún, Social Security Department, Iceland

HAUKSSON Helgi Johann, FAAS, Iceland

HENRY Sabine, Ligue Alzheimer, Belgium

HIMMER Eva, Hungarian Alzheimer's Association, Hungary

HOLMEROVA Iva, Czech Alzheimer's Society, Czech Republic

ILIEVA Irina, Alzheimer Bulgaria, Bulgaria

JACQUES Alan, Alzheimer Scotland, United Kingdom

JANSEN Sabine, Deutsche Alzheimer Gesellschaft, Germany

JOHANNSEN Peter, Alzheimerforeningen, Denmark

KLASUPA IIva, State Agency of Medicines, Latvia

KOGOJ Ales, Slovenian Alzheimer's Society, Slovenia

KOTRAS Nina, GAADRD, Greece

LECLERC Nathalie, Novartis, France

LONEUX Sylvie, Ligue Alzheimer, Belgium

O'CALLAGHAN Sarah, Alzheimer Society of Ireland, Ireland

PETITPRE Jean, France Alzheimer, France

RAUDSEPP Kristin, State Agency of Medicines, Estonia

RODRIGO Jesus Maria, Spanish Confederation of Families of Sufferers of

Alzheimer's and Other Dementias, Spain

SADOWSKA Alicja, Polish Alzheimer's Association, Poland

SALVINI Gabriella, Federazione Alzheimer Italia, Italy

SCERRI Charles, Malta Dementia Society, Malta

SELMES Micheline, Fundación Alzheimer España, Spain

SHARP Samantha, Alzheimer's Society, United Kingdom

SPARR Sigurd, Nasjonalforeningen Demensförbundet, Norway

TARISKA Peter, National Institute of Psychiatry and Neurology, Hungary

TELARANTA Pirkko, Alzheimer-keskusliitto, Finland

TSOLAKI Magda, GAADRD, Greece

TUDOSE Catalina, Societatea Alzheimer, Romania

TRAYKOV Latchezar, Alzheimer Bulgaria, Bulgaria

WILSON Gillian, Alzheimer Scotland, United Kingdom

WOLFENSBERGER Marianne, Association Alzheimer Suisse, Switzerland WORTMANN Marc, Alzheimer Nederland, Netherlands

ZINKE DOS REIS Maria do Rosario, Portuguese Confederation of Families of Sufferers of Alzheimer's and Other Dementias, Portugal
1. Donepezil is marketed in Europe under the name Aricept, rivastigmine as Exelon, galantamine as Reminyl and memantine as Ebixa or Axura.

2. Alzheimer's Society UK, Information sheet on Drug treatments for Alzheimer's disease - Aricept, Exelon, Reminyl and Ebixa, August 2003.

3. Alzheimer's Society UK, op. cit.

4. Alzheimer's Society UK, op. cit.

5. Reimbursement of donepezil is limited to the generic versions of this product.

6. Although individual health trusts are free to reimburse memantine, the Scottish Medicines Consortium rejected their use through the NHS and the opinion of NICE was pending when this publication went to print.

7. The MMSE (Folstein et al., 1975) is a quick test that gives an overall estimate of a person's intellectual capacity and can therefore be used to give a rough assessment of the progress of dementia over time. It gives a score from 30 (full mental capacity) to 0 (severe impairment).

8. Oude Voshaar RC, Burns A, Olde Rikkert MGM, Alarming arbitrariness in $\mathrm{EU}$ prescription and reimbursement criteria for antidementia drugs, Int J Geriatr Psychiatry, 2006; 21:29-31.

9. Unless obtained from our member organisations, we included data from Oude Voshaar, et.al., op. cit.

10. Unless obtained from our member organisations, we included data from R.C. Oude Voshaar et al., op.cit.

11. Although an application for reimbursement can be made by an doctor on behalf of a patient, the diagnosis must have been made by a specialist (neurologist, psychiatrist or geriatrician).

12. Any doctor can prescribe antidementia drugs, but reimbursement can only be given if the diagnosis has been established by a specialist.

13. Although prescriptions can be filled in by any doctor, the diagnosis needs to be confirmed by a specialist.
14. Norway specifies that treatment decisions should be made by a doctor with an interest in and knowledge of dementia, but does not restrict treatment decisions to specialist doctors.

15. For patients with MMSE scores higher than 26, more extensive neuropsychological examinations have to be carried out that indicate cognitive decline consistent with Alzheimer's disease.

16. The NICE guidance in existence (September 2006) allows general practitioners to continue treatment under shared care protocols.

17. Wilkinson $D$, et al., Inequalities in dementia care across Europe: An Agenda for Change, Int I Clin Pract, 2005:59(S146):17-24.

18. Waldemar G, Phung KTT, Burns A, et al., Access to diagnostic evaluation and treatment for dementia in Europe, Int I Geriatr Psychiatry, in press.

19. Wilkinson $D$, op. cit.

20. Waldemar $\mathrm{G}$, op. cit. 